\title{
Factors Influencing the Shallow Groundwater Quality in Four Districts with Different Characteristics in Urban Area (Douala, Cameroon)
}

\section{Beatrice Ketchemen-Tandia, Suzanne Ngo Boum-Nkot, Seth Rodrigue Ebondji, Bertil Yvon Nlend, Huguete Emvoutou, Olivia Nzegue}

Department of Geosciences, University of Douala, Douala, Cameroon

Email: suzyboum@yahoo.fr

How to cite this paper: Ketchemen-Tandia, B., Boum-Nkot, S.N., Ebondji, S.R., Nlend, B.Y., Emvoutou, H. and Nzegue, O. (2017) Factors Influencing the Shallow Groundwater Quality in Four Districts with Different Characteristics in Urban Area (Douala, Cameroon). Journal of Geoscience and Environment Protection, 5, 99-120. https://doi.org/10.4236/gep.2017.58010

Received: June 2, 2017

Accepted: July 31, 2017

Published: August 3, 2017

Copyright $\odot 2017$ by authors and Scientific Research Publishing Inc. This work is licensed under the Creative Commons Attribution International License (CC BY 4.0).

http://creativecommons.org/licenses/by/4.0/

\begin{abstract}
This study examines groundwater samples from four areas under different conditions. Variations amongst the areas are due to the distinct topography, demographics, and socio-economic activities. A qualification of the groundwater using the following parameters; $\mathrm{pH}$, electric conductivity and nitrate analysis yielded results depicting the deplorable state of the unconfined aquifer; which is even worst in the densely populated and low-lying areas. These unfavorable conditions are present in the older districts (Bependa and Ndogbong) compared to the younger and least populated (urbanized) districts (Ndogpassi and Logpom). The poor quality of groundwater could be due to contamination by sewage from latrines and surface discharges. Nevertheless, nitrate contents $(>241 \mathrm{mg} / \mathrm{l})$ in these districts indicate that pollution has not reached the alarming levels observed in other West African cities (nitrates > $400 \mathrm{mg} / \mathrm{l}$ ). Relatively low concentrations of nitrate in groundwater of the studied areas could be due to volatilization phenomena common in the unconfined aquifers in Douala. We however remarked that most of the studied wells are not used as drinking water, because they present particular health risks to humans.
\end{abstract}

\section{Keywords}

Shallow Groundwater, Quality, Districts, Urban, Chemistry

\section{Introduction}

In recent decades it has become evident in many countries that groundwater is 
the most important natural resource. It constitutes the main part of total water resources in many countries. For example: in Tunisia, groundwater makes up $95 \%$ of the country's total water resources, $83 \%$ in Belgium, and $75 \%$ in the Netherlands, Germany and Morocco. In most European countries (Austria, Belgium, Denmark, Hungary, Romania and Switzerland) groundwater makes up $~ 70 \%$ of the total water consumption [1]. In Africa, water supply in most cities depends on groundwater exploited through wells, boreholes and springs. It is also the main water supply source of $55 \%$ of the population of Bamako [2] and nearly $70 \%$ in Lusaka [3] According to the World Bank, over 50\% of Nigeria's population depends on groundwater [4]. High quality of groundwater is particularly essential in domestic use and drinking water supply. Thus, the study of groundwater quality is imperative [5] [6], because poor quality water may have adverse effects on the user's health. The pollutant might be a manufactured chemical, but it's usually microbial contamination. Contamination can also result from naturally occurring mineral and metallic deposits in rock and soil [7] [8]. The most important contaminant in urban areas is domestic sewage where there is no sewage collection system and treatment [9] [10] [11]. The most common pollutants are mainly nitrogen compounds (e.g. ammonium, nitrite and specially nitrate) [12]. The high concentration of nitrates in groundwater is a problem of the century, because it decreases the quality of water as a potential resource, a health risk to the population thus, compromising the socio-economic development of the country [1] [13]. High concentration of nitrates therefore causes diseases especially in pregnant women and babies (infant methemoglobinemia, risk of stomach cancer).

During the last two decades many authors have worked on this problems related to nitrates in groundwater in some agglomerations of Saharan Africa. For example [14] found nitrate concentrations in Dakar (Senegal), exceeding 500 $\mathrm{mg} / \mathrm{l}$; and they interpreted the high concentrations to be related to permeable household pit toilets that are virtually in contact with the groundwater; as well as the influence of high evaporation during the dry season. A study of the impact of land use and hydrogeological setting on the shallow groundwater quality in the peri-urban area of Kampala, Uganda by [15] demonstrated that the water table in the area responded rapidly to short rains, due to the previous and shallow vadose zone which consists of unconsolidated material. They also showed that this anthropogenically influenced vadose zone has a limited contaminant attenuation capacity, which results in widespread contamination of the groundwater with high organic matter $(779 \mathrm{mg} \mathrm{NO} / 1)$ originating from multiple sources following rainfall. [16] examined 1292 wells in the shallow ground water in Ontario (Canada) and found that the degree of nitrate pollution depends mainly on the depth of the ground water. [17] examined nitrates concentration in the groundwater in China and they showed that groundwater nitrate concentrations were highest in industrial areas, followed by the urban and rural areas, with the lowest values found in the unused land. Studies conducted by the Douala (Cameroon) municipality have revealed that there are approximately 100,000 hand dug wells sup- 
plying water to the households of very low income population in Douala City [18]. The reason for the proliferation of wells is the incapacity of the national water company (CAMWATER) to supply enough drinking water to the population. In fact, with less than 70,000 subscribers over a target population of 3 million, CAMWATER covers the needs of $<30 \%$ of the population. The rest of the population gets water directly from springs, traditional wells or boreholes, found allover without information on the water quality. As a result the population suffers from many waterborne diseases with cholera being the most frequent that killed many people in 2004 [18]. Currently, there is a lack of information and understanding of $\mathrm{NO}_{3}^{-}$input and its effect on the groundwater quality and the health of the ecosystem health within the densely populated areas of Douala, Cameroon. Few studies have been carried out [19]-[24] and established the level of nitrate concentration in shallow groundwater is up to $160 \mathrm{mg} / \mathrm{l}$. These studies show the nitrate to be of anthropogenic origins.

In this paper four districts (urban areas) with different characteristics are examined. The quality of the shallow groundwater is presumed to be significantly different in the four areas due to the different demographic and socioeconomic characteristics. The main aim of this research work is to apply hydrochemistry and statistical analysis to identify the factors responsible for nitrate contamination in the groundwater in the selected areas in the economic capital of Cameroon. This study is the first to be conducted in an urban environment in the tropical humid area with such a high dynamic charging.

\section{Study Area}

Investigations were carried out in the Bependa, Logpom, Ndogpassi and Ndogbong districts. These settlements are located in the Douala (Littoral region), economic capital of Cameroon, located between latitudes $3^{\circ} \mathrm{N}-5^{\circ} \mathrm{N}$ and $9^{\circ} 30^{\prime} \mathrm{E}$ $11^{\circ} 42^{\prime} \mathrm{E}$ extending to the coastal areas of the South-West Cameroon (Figure 1).

The Douala metropolitan area alone has a population of 3 million, estimated to be $10 \%$ of Cameroon's population i.e. about $20 \%$ of the urbanized population of the country. Douala harbors almost 80 percent of Cameroon industries [25], and because of its nature and diverse economic activity, it is the fastest growing area in the country. Demographic projections suggest this upward trend will continue for some time. The average annual rate of population growth is estimated at $5 \%$ over the last 30 years, which is well above the national rate of $2.8 \%$ [26].

Waste water and solid waste management practices in the area are grossly inadequate (or nonexistent) and services are misused, resulting in environmental degradation similar to other such settlements in the country and in the world

(e.g. Buyo in South-west of Cote d'Ivoire, Ilorin the capital of Kwara State in Nigeria, Dharavi in Bombe and Barrio San Jorge in Buenos Aires). In Douala, sanitary facilities [septic tanks] are largely financed by private households, while public sanitation is marginal or absent. The common mode of wastewater disposal in the city of Douala is still through hand dug latrines (pit toilets). About 


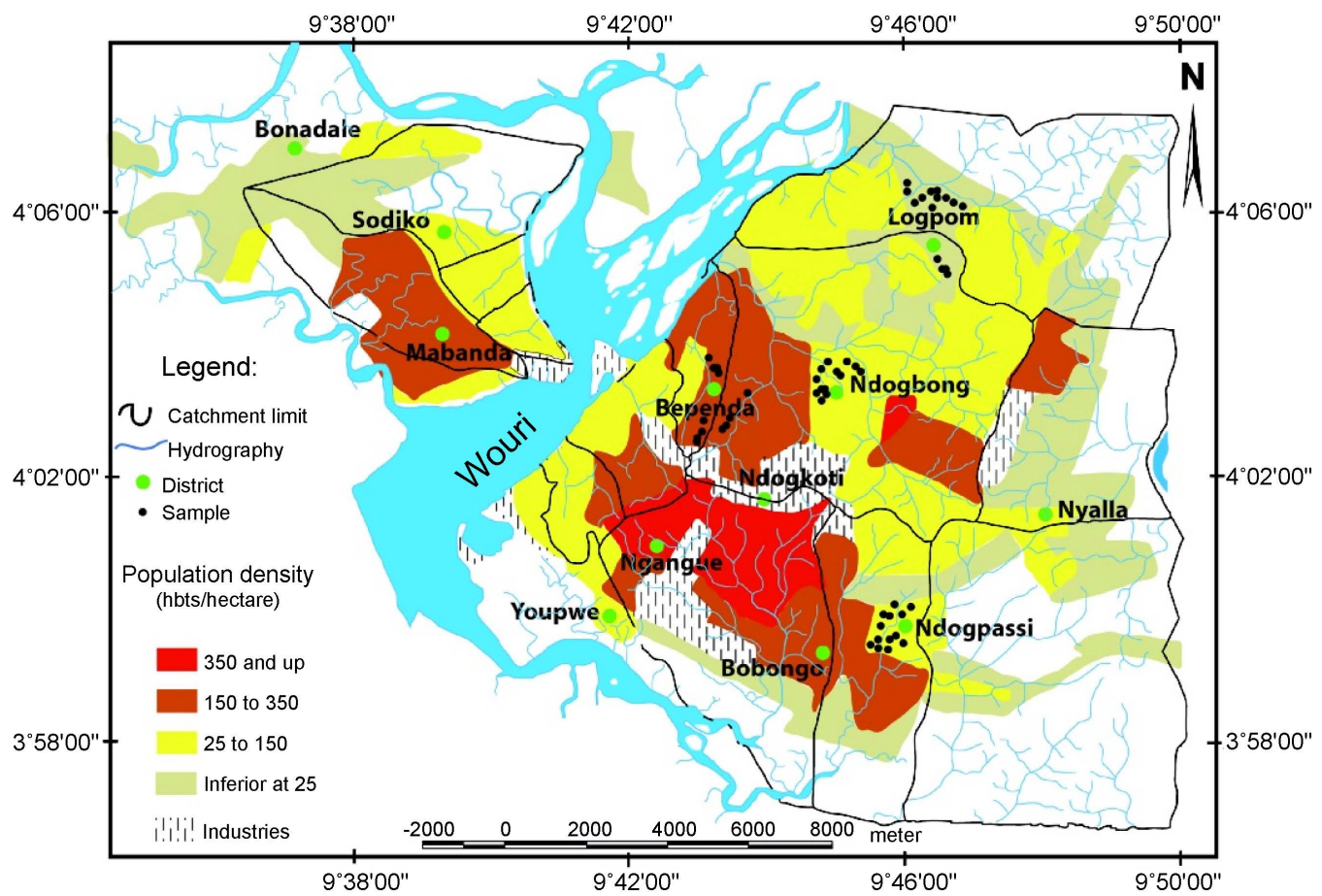

Figure 1. Map of the examined settlements and population density of each district.

$25 \%$ of the population uses the latter to dispose of excrement in the Douala area [27]. Collective sanitation is found only in a few well-structured districts is non-functional due to lack of implementation/maintenance of the operating system. The operation of these facilities was not well studied to assure perfect functionality and durability of structures. Open dumping is a major form of solid waste disposal in this area and in some cases human excrement which contains pathogens.

A piped-borne water system exists in the area, but because of the high costs imposed by the private owners, it serves only a small percentage of the population.

Generally, Douala is low lying with a height of $60 \mathrm{~m}$ above sea level. The Wouri and the Dibamba rivers constitute the drainage system in the entire Douala metropolitan city and they flow all year round. The Wouri flows through Akwa, Bonaberi (in the west part of the town) and part of the Bassa (eastern part of Douala) while the Dibamba flows through the eastern outskirt of the town. These rivers are fed by many tributary streams that are normally laden with solid and liquid wastes from industries, households and open garbage dumps. Human activities within the river catchments range from subsistence farming through rural settlements to larger cities hosting a variety of industries (e.g. Fertilizer, palm oil mill, cement, ceramics, gas, salt, metal work, soap, textiles, metallurgy, chemicals, brewery, glass, boat and ship yards).

The four districts selected for this study to characterize the unconfined shallow groundwater, is based on the demographic and social-economic differences: 1) Bependa is located in the western part of Douala City, to the eastern shore of 
the Wouri River and $\sim 2 \mathrm{Km}$ from the city center. It has a population density between 150 - 350 inhabitants $/ \mathrm{km}^{2}$. It is one of the lowest lying areas of the Douala city $(\sim 15 \mathrm{~m})$. The area, though mainly residential, has many low-income economic activities for the residents. These are low-income jobs ranging from selling cooked food in markets through street hawking to retail shops. More than 30 years ago this area was used as the only garbage dump of Douala city.

2) The morphology of the Ndogbong area is made by plateaus (52 $\mathrm{m}$ ) and valleys $(20 \mathrm{~m})$. The natives have built their homes on the plateaus. This district is one of the oldest settlements in Douala, thus benefits from a well-conceived urban development plan with the water distribution system provided by a private company (CAMWATER). The valleys have the typical urban city slums, which are largely unplanned and where the highest rate of population growth has very low incomes. The population density is between 25 - 150 inhabitants $/ \mathrm{km}^{2}$.

3) Like Ndogbong, Logpom is characterize by a defined urban development plan and located in the Northern part of Douala. It is one of the highest areas in Douala $(50 \mathrm{~m})$. It is also the least populated $\left(<25\right.$ inhabitants $\left./ \mathrm{km}^{2}\right)$ and the youngest area among the four districts studied.

4) Ndogpassi, in the southern part of Douala, is a typical urban slum that is largely unplanned and has one of the highest population growth rates with 35 $\mathrm{m}$. It is also an outskirt settlement characterized by the same population density as Ndogbong (25 - 150 inhabitant/hectare) but younger. Like Bependa, it is characterized by market and retail shops.

The regional climate is equatorial type influenced by monsoon winds with 9 months of rainy season (March - November), a maximum rainfall in August. The metrological data obtained 1951-2015 (65 years) through the Douala Airport station, indicate the annual average rainfall in Douala is $4000 \mathrm{~mm}$, the wettest African urban center. Temperatures vary between $24.3^{\circ} \mathrm{C}-24.3^{\circ} \mathrm{C}$ with a mean of $27^{\circ} \mathrm{C}$ and the average annual evaporation is $<1300 \mathrm{~mm}$. The abundance of rainfall in the region is accompanied by a heavy cloud cover maintaining a constant high humidity. The maximum values vary very little from month to month, for an annual average relative humidity of $82 \%$. This high relative humidity is a consequence of the regularity with which the SW monsoon blows in this part of Cameroon.

\section{Geology and Hydrogeology}

Geologically, the Douala region is unconformably overlain by a sedimentary sequence ranging from Cretaceous to recent (Figure 2). This sequence is made up of six formations (Wouri, Matanda, Souelaba, N'Kapa, Logbaba and Mundeck) described [28] [29] [30] [31]. The study area reposes directly on the Mio-Pliocene to recent alluvial sediments of the basin, which constitutes the Wouri Formation. Generally, it consists of unconsolidated fine to coarse-grained sand 


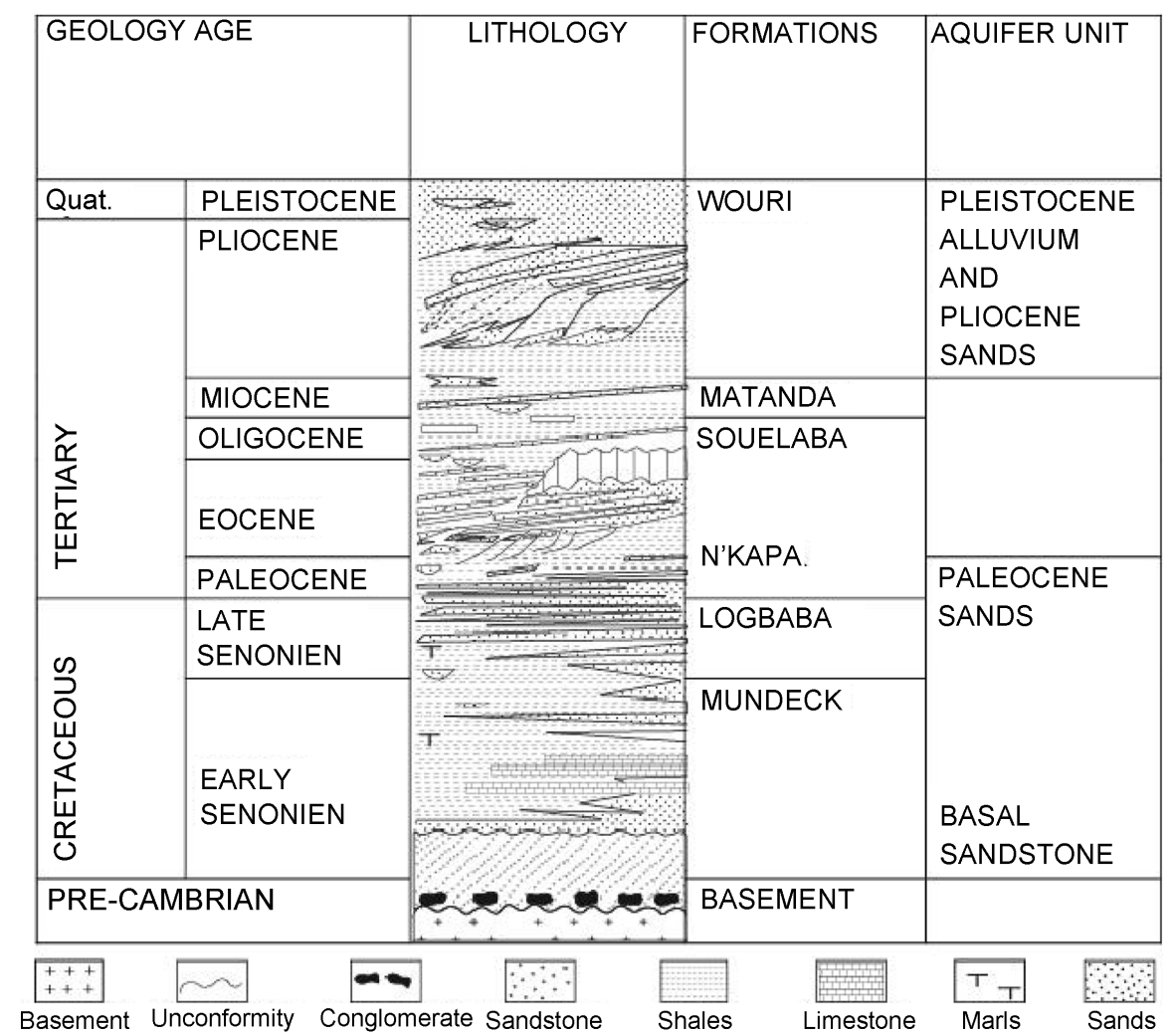

Figure 2. Chrono-stratigraphic column of the Douala basin and major aquifer units (adapted from Regnoult, 1986; Manga, 2008).

and gravel with intercalation of silt and clay in varied proportions. The alluvium is composed predominantly of quartz and kaolinite [32], with a general thickness that ranges between $50-60 \mathrm{~m}$ [33].

The shallow unconfined groundwater of Douala is characterized by a porous vadose zone. Additionally, the topography of the area is such that flooding is a common occurrence following heavy rainfall.

As a result of low altitude, the aquifer in the area is very vulnerable to contamination. The quick response to rainfall implies rapid recharge through a highly permeable vadose zone.

The shallow aquifer (Mio-Pliocene sands and Quaternary alluvium of unknown boundaries) is a multi-layered system with unconfined and confined groundwater which is mainly fed by precipitation [34]. Waste water from drainage channels also infiltrate into this aquifer. The lateral lithological variations in this aquifer make it very complex. Several lenses of channel-filled sands, intercalated in clay layers, occur within the main aquifer, acting as a perched aquifer. Many streams drain the area and may also be recharged by the aquifer during the dry season. Average groundwater level fluctuation ranges between $0.3 \mathrm{~m}$ and $1.60 \mathrm{~m}$, respectively during dry and wet seasons in the unconfined shallow aquifer where hand dug wells have been sampled in the study area. This aquifer records water levels of approximately $1-20 \mathrm{~m}$ and is highly exploited by locally hand dug wells. 


\section{Analysis Procedure}

Water samples from 79 selected wells were collected during the dry season of February 2012, from the selected districts of Douala, as follows: Bependa (13), Ndogbong (21), Ndogpassi (20) and Logpom (25). Locations (longitude and latitude) and altitudes of selected sample sites were determined on the field using a Garmin GPS. Physico-chemical parameters like electric conductivity (EC), pH and temperature were measured in situ with a WTW 330i HACH multi-parameter. The depth of the water table was also determined in situ during the sampling. All the samples were filtered on site through a $0.45 \mu \mathrm{m}$ syringe filter and poured into two 125-ml-capacity plastic bottles (for anions and cations) after rinsing with the sample and preserved airtight to avoid evaporation. The cations samples were acidified to a $\mathrm{pH}$ of $<2$ with ultra-pure nitric acid. After the sampling, water was immediately transported under low temperature conditions in ice box and stored at $4^{\circ} \mathrm{C}$ until analysis was done at the hydrochemistry laboratory of the Cheik Anta Diop University, Dakar (Senegal). The major ions that were analyzed included; $\mathrm{Na}^{+}, \mathrm{K}^{+}, \mathrm{Ca}^{2+}, \mathrm{Mg}^{2+}, \mathrm{Cl}^{-}, \mathrm{HCO}_{3}^{-}, \mathrm{SO}_{4}^{2-}$ and $\mathrm{NO}_{3}^{-}$.

$\mathrm{Na}^{+}, \mathrm{K}^{+}, \mathrm{Ca}^{2+}$ and $\mathrm{Mg}^{2+}$ concentrations were measured using the Dionex DX 120, Ion Chromatograph CS 12 column (California, USA) while $\mathrm{Cl}^{-}, \mathrm{SO}_{4}^{2-}$ and $\mathrm{NO}_{3}^{-}$where determined by Molecular Absorption Spectrophotometer (Jasco 7800 brand). Bicarbonate $\left(\mathrm{HCO}_{3}^{-}\right)$ion concentrations were obtained through titration of $0.05 \mathrm{~N} \mathrm{H}_{2} \mathrm{SO}_{4}$. The analytical precision of cations $\left(\mathrm{Na}^{+}, \mathrm{K}^{+}, \mathrm{Ca}^{2+}, \mathrm{Mg}^{2+}\right)$ and anions $\left(\mathrm{Cl}^{-}, \mathrm{HCO}_{3}^{-}, \mathrm{SO}_{4}^{2-}\right.$ and $\left.\mathrm{NO}_{3}^{-}\right)$was verified using ionic balance error (IBE) on the basis of ions expressed in meq/l [35]. IBE was observed to be within a limit of $\pm 10 \%$ for all the investigated samples. The diagram software [36] was used to determine the different chemical facies of water in the study areas.

Descriptive statistics was done using the R program (version 3.1.3) and Excel 2013 for Windows. Univariate statistics was used to compare the water quality with [37] standards.

\section{Results and Discussion}

Table 1 is a display of the chemical constituents ( $\mathrm{pH}, \mathrm{EC}$, nitrate and major ion concentrations) of groundwater samples.

\subsection{Physico-Chemical Parameters}

\subsubsection{Depth}

Amongst the natural factors, the depth of the groundwater is very important because groundwater can be found at a reasonable depth where the infiltration of contaminants is more or less difficult [38]. Another factor which can influence contamination is permeability of the soil.

In Figure 3 significant differences amongst the studied districts can be observed. The average depth is approximately $6 \mathrm{~m}$ in Logpom and Ndogpassi districts. The average groundwater depth does not exceed $4 \mathrm{~m}$ in Ndogbong and 2 
Table 1. (a) Physico-chemical characteristics of groundwater in four districts (Bepanda, Logpom, Ndogpassi \& Ndogbong) of Douala, and (b) compliance to WHO (2004) drinking water standards.

\begin{tabular}{|c|c|c|c|c|c|}
\hline (a) & Bepanda & Logpom & Ndogpassi & Ndogbong & WHO (2004) limit \\
\hline $\mathrm{pH}$ & $3.5-6.9$ & $4.5-6.09$ & $4.08-5.8$ & $4.34-7.2$ & $6.5-8.5$ \\
\hline $\mathrm{EC}(\mu \mathrm{S} / \mathrm{cm})$ & $332-1646$ & $42-250.8$ & $25.5-126$ & $103-483$ & 750 \\
\hline $\mathrm{Ca}(\mathrm{mg} / \mathrm{l})$ & $14.6-76.2$ & $1.26-19.76$ & $1.3-18.9$ & $2.2-101.6$ & 75 \\
\hline $\mathrm{Mg}(\mathrm{mg} / \mathrm{l})$ & $1.3-25.3$ & $0.54-15.84$ & $0.3-1.1$ & $0.5-3.31$ & 30 \\
\hline $\mathrm{Na}(\mathrm{mg} / \mathrm{l})$ & $32.2-170.9$ & $2.7-20.6$ & $2.0-16.24$ & $8.1-38.5$ & 200 \\
\hline $\mathrm{K}(\mathrm{mg} / \mathrm{l})$ & $2.2-33.5$ & $0.1-6.9$ & $0.3-6.1$ & $2.7-28.9$ & 100 \\
\hline $\mathrm{Cl}(\mathrm{mg} / \mathrm{l})$ & $33.6-162$ & $0.1-1.8$ & $1.8-13.8$ & $2.3-21.5$ & 250 \\
\hline $\mathrm{NO}_{3}(\mathrm{mg} / \mathrm{l})$ & $72-241.1$ & $0.6-27$ & $0.6-40.9$ & $16.6-165.1$ & 50 \\
\hline $\mathrm{SO}_{4}(\mathrm{mg} / \mathrm{l})$ & $0-62.6$ & $1-58$ & $0-14.8$ & $0-29.3$ & 250 \\
\hline $\mathrm{HCO}_{3}(\mathrm{mg} / \mathrm{l})$ & $0-244$ & $15.25-119.15$ & $0-63.25$ & $6.1-284.3$ & 200 \\
\hline (b) & Bepanda & Logpom & Ndogpassi & Ndogbong & WHO (2004) limit \\
\hline $\mathrm{pH}$ & 92.3 & 100 & & 85.7 & $6.5-8.5$ \\
\hline $\mathrm{EC}(\mu \mathrm{S} / \mathrm{cm})$ & 38.5 & 0.0 & 0.0 & 0.0 & 750 \\
\hline $\mathrm{Ca}(\mathrm{mg} / \mathrm{l})$ & 7.7 & 0.0 & 0.0 & 9.5 & 75 \\
\hline $\mathrm{Mg}(\mathrm{mg} / \mathrm{l})$ & 0.0 & 0.0 & 0.0 & 0.0 & 30 \\
\hline $\mathrm{Na}(\mathrm{mg} / \mathrm{l})$ & 0.0 & 0.0 & 0.0 & 0.0 & 200 \\
\hline $\mathrm{K}(\mathrm{mg} / \mathrm{l})$ & 0.0 & 0.0 & 0.0 & 0.0 & 100 \\
\hline $\mathrm{Cl}(\mathrm{mg} / \mathrm{l})$ & 0.0 & 0.0 & 0.0 & 0.0 & 250 \\
\hline $\mathrm{NO}_{3}(\mathrm{mg} / \mathrm{l})$ & 100 & 0.0 & 10 & 47.6 & 50 \\
\hline $\mathrm{SO}_{4}(\mathrm{mg} / \mathrm{l})$ & 0.0 & 0.0 & 0.0 & 0.0 & 250 \\
\hline $\mathrm{HCO}_{3}(\mathrm{mg} / \mathrm{l})$ & 7.7 & 0.0 & 0.0 & 9.5 & 200 \\
\hline
\end{tabular}

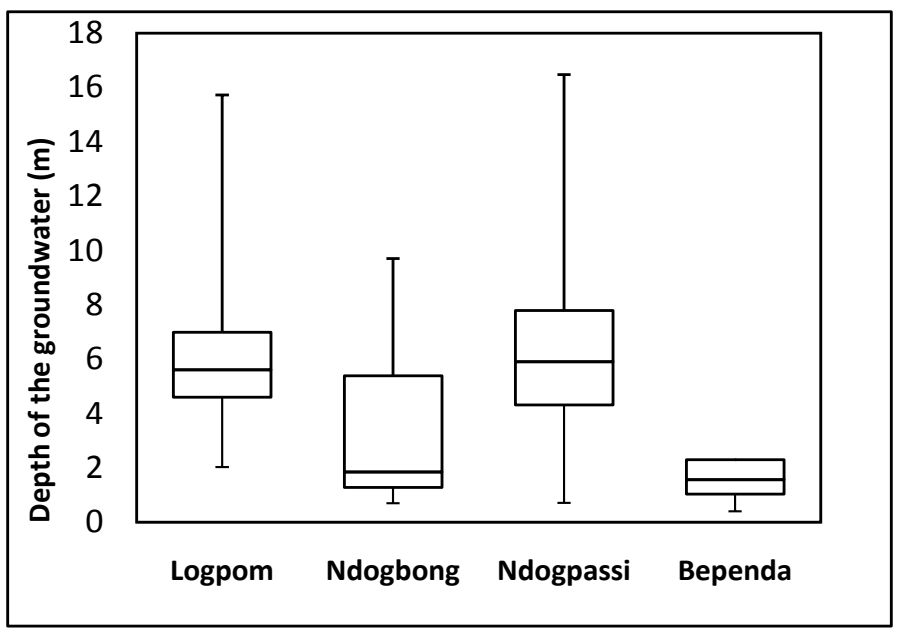

Figure 3. Groundwater depth $(\mathrm{m})$ in the studied districts.

$m$ in Bependa. Based on the groundwater depth, Bependa and Ndogbong can be considered the most endangered districts. However, the soil in most parts of the four districts is sandy thus very permeable making the groundwater exposed to 
contamination.

The correlative analyses between Electrical conductivity (EC) and Depth did not show any influence of the groundwater level to the groundwater mineralization except for Logpom (Figure 4) which shows a negative trend between EC and Depth. This means that the deeper wells in this district which are characterized by less density of population are less contaminated.

\subsection{2. $\mathrm{pH}$}

There is no significant difference between the four settlements regarding $\mathrm{pH}$. The values range from 3.5 to 7.2 (Table 1), most samples are either acidic or slightly neutral. The Bependa district presents a wider range of $\mathrm{pH}$-values (Figure 5) and the most acidic sample being BE $12(\mathrm{pH}=3.5)$ while Logpom $\mathrm{pH}$-value distribution is narrow $(4.6-5.3)$ and relatively close to the input function $(5.5$ - 5.8) [23].

[24] showed that the acidity of groundwater in Quaternary alluvium of Douala may have resulted from origins such as; acid rain, coastal atmospheric deposition, anthropogenic activities and cation exchange from marine sodium with

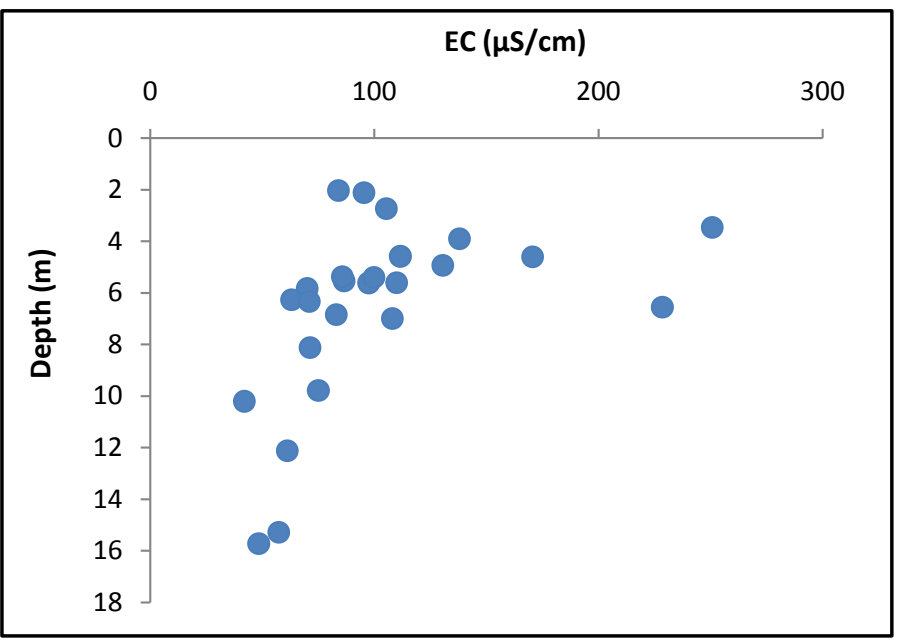

Figure 4. Depth (m) and electrical conductivity $(\mu \mathrm{s} / \mathrm{cm})$ in Logpom district.

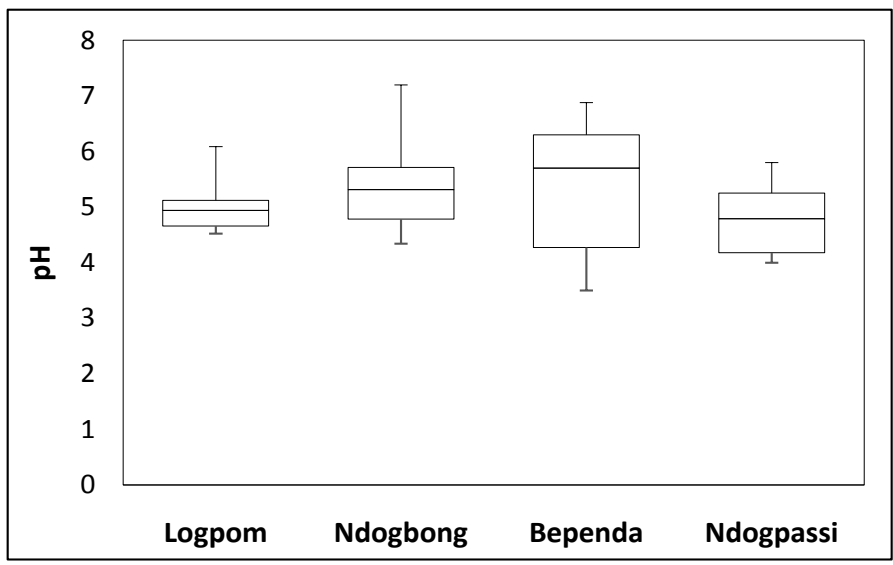

Figure 5. The $\mathrm{pH}$ of groundwater in the studied districts. 
hydrogen and/or aluminium ions bound in the soil. The silicate nature of soil and the oxidation of organic matter could also increase the acidic nature of groundwater.

\subsubsection{Electrical Conductivity}

Figure 6 is a display of the EC which gives the total ion content of water samples [39]. It shows a higher and wider range $(332-1646 \mu \mathrm{S} / \mathrm{cm})$ in Bependa than in Ndogbong (103 - $483 \mu \mathrm{S} / \mathrm{cm})$, Logpom $(42-250 \mu \mathrm{S} / \mathrm{cm})$ and Ndogpassi $(2-57.5$ $\mu \mathrm{S} / \mathrm{cm})$.

Based on the depths of the groundwater, the wide distribution of $\mathrm{pH}$ and the high EC, Bependa can be considered the most vulnerable area, which could also be due to the relativity high population density.

\subsection{Major Ions and Water Type}

The major cations and anions make up the bulk of groundwater quality [40], and it is widely known that the major ions dissolved in groundwater could have originated from one of three sources: juvenile rainwater, water-soil and water-rock interactions and anthropogenic influences [41].

The general order of dominance of the cations is: $\mathrm{Na}^{+}>\mathrm{Ca}^{2+}>\mathrm{K}^{+}>\mathrm{Mg}^{2+}$ for samples in Ndogpassi, Ndogbong and Bependa. Meanwhile, the area with low population density of Logpom district shows a different order: $\mathrm{Na}^{+}>\mathrm{Ca}^{2+}>$ $\mathrm{Mg}^{2+}>\mathrm{K}^{+}$. Sodium $\left(\mathrm{Na}^{+}\right)$is primary natural cation which generally occurs in lower concentrations in fresh water than the other cations excluding $\mathrm{K}^{+}$. Sodium is the most dominant element in the groundwater of the study area. The average concentration of $\mathrm{Na}^{+}$in Bepanda samples is the highest $(63.15 \mathrm{mg} / \mathrm{l})$ followed by Ndogbong samples $(20.49 \mathrm{mg} / \mathrm{l})$. These high $\mathrm{Na}^{+}$values could be related to weathering of minerals like Na-plagioclase and/or anthropogenic sources such as domestic and animal waste [23] [24]. The anions order is $\mathrm{NO}_{3}^{-}>\mathrm{HCO}_{3}^{-}>$ $\mathrm{Cl}^{-}>\mathrm{SO}_{4}^{2-}$ in Ndogpassi and Bepanda, $\mathrm{NO}_{3}^{-}>\mathrm{HCO}_{3}^{-}>\mathrm{SO}_{4}^{2-}>\mathrm{Cl}^{-}$in Ndogbong area and $\mathrm{HCO}_{3}^{-}>\mathrm{NO}_{3}^{-}>\mathrm{SO}_{4}^{2-}>\mathrm{Cl}^{-}$for Logpom samples.

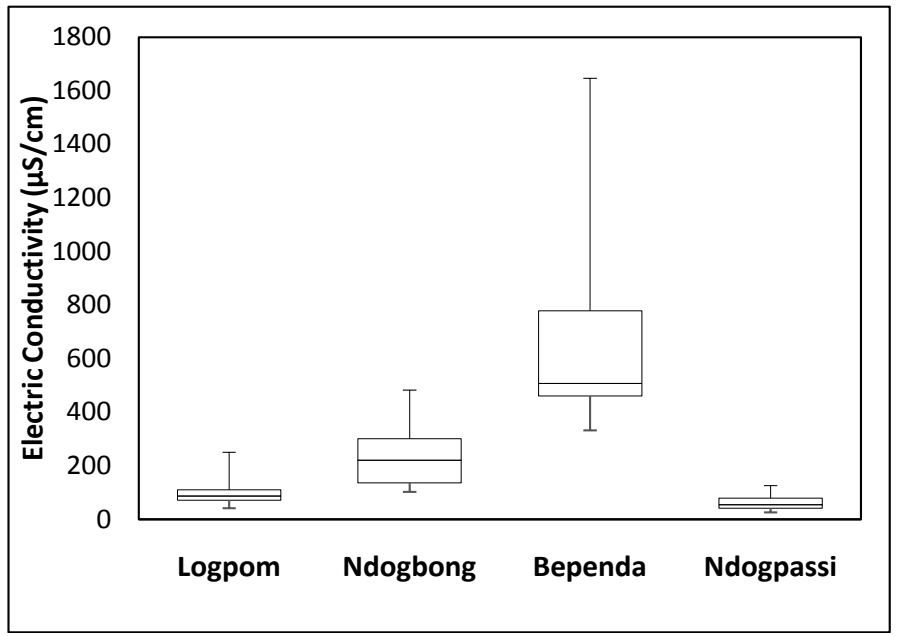

Figure 6. Electrical conductivity $(\mu \mathrm{S} / \mathrm{cm})$ in the studied districts. 
The natural source of sulfate and chloride is seawater and evaporites; and the main anthropogenic sources are urban, industrial and agricultural wastewaters. The $\mathrm{pH}$ of the groundwater which ranges between 3.5 and 7.2 with a mean of 5.1 indicates the presence of dissolved carbonates predominantly in the form of $\mathrm{HCO}_{3}^{-}$[42]. Carbonate and/or alumino-silicate minerals weathering and a secondary contribution from dissolution of $\mathrm{CO}_{2}$ gases are the primary source of $\mathrm{HCO}_{3}^{-}$in groundwater [43] [44]. In an attempt to determine the water types, the chemical compositions of the analyzed water samples were plotted on Piper tri-linear equivalence diagram [45] (Figure 7).

Concentration of nitrate was considered when plotting the diagram, because of the relative abundance in many water samples. This figure shows that the investigated areas are characterized by low concentrations of sulphate ions but there is a clear trend from $\mathrm{HCO}_{3}^{-}$to $\mathrm{Cl}-\mathrm{NO}_{3}$ for samples in Bepanda, Ndogpassi and Ndogbong. For cations we observed trends from $\mathrm{Ca}^{2+}$ pole to $\mathrm{Na}^{+}$pole suggesting an ion exchange process [46] [47]. About 56\% of the groundwater samples from Logpom present a $\mathrm{Ca}-\mathrm{HCO}_{3}$ facies and $36 \%$ fall in the $\mathrm{Na}-\mathrm{HCO}_{3}$ subfield; $8 \%$ have no Ca- $\mathrm{SO}_{4}$ and $\mathrm{Na}-\mathrm{NO}_{3}$ facies. For Ndogpassi and Logpom, $76.2 \%$ and $65 \%$ respectively fall in the $\mathrm{Na}-\mathrm{K}-\mathrm{Cl}-\mathrm{NO}_{3}$-subfield; $19 \%$ and $20 \%$ are close to the $\mathrm{Ca}-\mathrm{Mg}-\mathrm{HCO}_{3}$-subfield; $4.8 \%$ and $5 \%$ correspond to the $\mathrm{Na}-\mathrm{SO}_{4}{ }^{-}$ subfield and $\sim 10 \%$ of groundwater samples in Ndogpassi have a $\mathrm{Na}-\mathrm{HCO}_{3}$ facies. The case of Bepanda is very typical. All the water samples in this area fall in the $\mathrm{Na}-\mathrm{K}-\mathrm{Cl}-\mathrm{NO}_{3}$-sub-field.

$\mathrm{Ca}-\mathrm{HCO}_{3}$ water type represent groundwaters that either contain waters at the

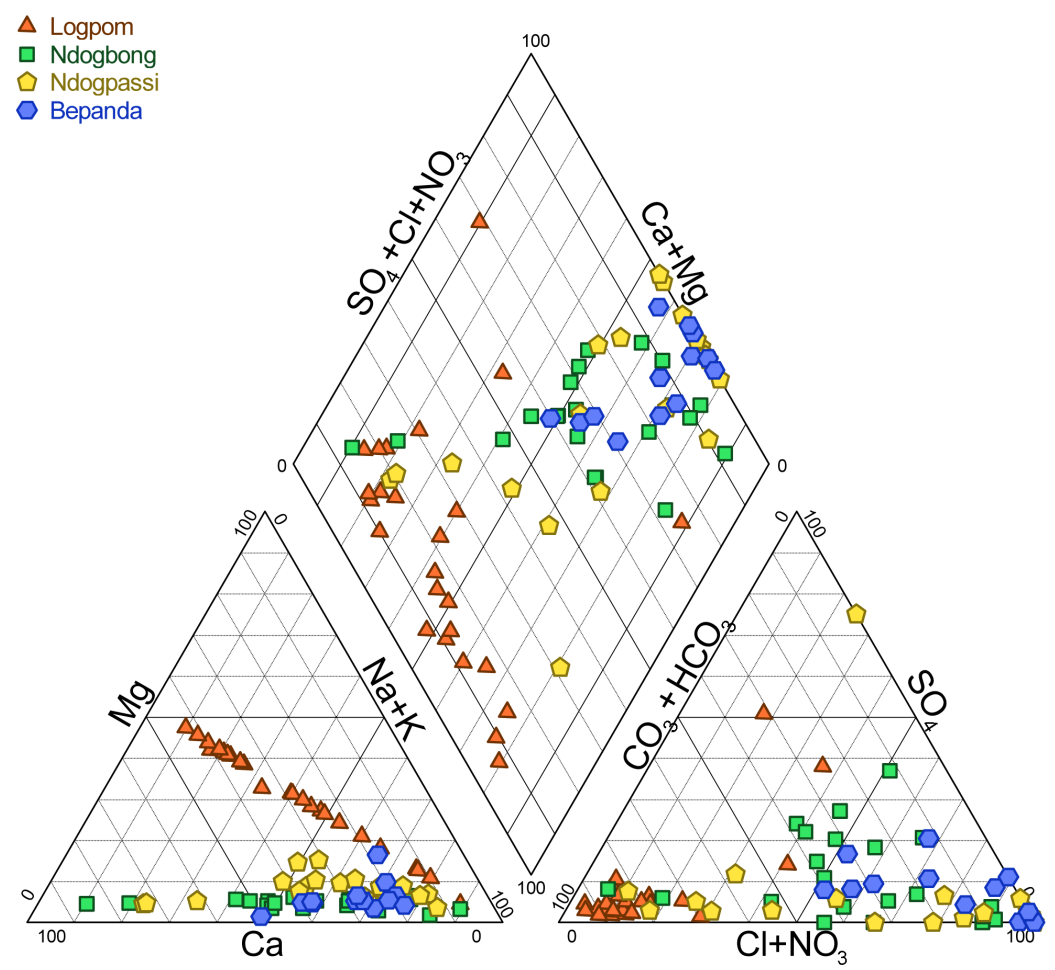

Figure 7. Piper diagram for Logpom, Ndogbong, Ndogpassi and Bepanda groundwater. 
early stages of geochemical evolution (recent recharge) or rapidly circulating groundwater which have not undergone significant water-rock interactions [48] [49]. Water groups represented by $\mathrm{Ca}-\mathrm{HCO}_{3}$ and $\mathrm{Na}-\mathrm{HCO}_{3}$ are weakly mineralized waters circulating mainly in Logpom district which have the lowest density of population among the study areas. However, some samples of Ndogbong and Ndogpassi have chemical facies.

$\mathrm{Na}-\mathrm{Cl}-\mathrm{NO}_{3}, \mathrm{Na}-\mathrm{SO}_{4}$ and $\mathrm{Ca}-\mathrm{SO}_{4}$ water types are characteristic of anthropogenic pollution, indicating the influence of human activities on water chemistry [50].

\subsection{Nitrate Contamination in Groundwater}

Nitrate is an important environmental pollutant, derived from atmospheric precipitation, agricultural fertilizers, human and animal excrement, biological decomposition and nitrification of organic $\mathrm{N}$ and $\mathrm{NH}_{4}$ [51]. Anion chemistry shows $\mathrm{NO}_{3}^{-}$to be the dominant anion in the water samples (Ndogpassi, 16.99 $\mathrm{mg} / \mathrm{l}$; Ndogbong, $59.63 \mathrm{mg} / \mathrm{l}$; and Bependa $134.12 \mathrm{mg} / \mathrm{l}$ ) while Logpom samples show the following descending order of dominance $\mathrm{HCO}_{3}^{-}>\mathrm{NO}_{3}^{-}>\mathrm{SO}_{4}^{2-}$. About $31 \%$ of groundwater samples collected during this study show nitrates concentration above the maximum contaminant level $(M C L)$ defined by World Health Organization (WHO) and Cameroon Drinking Water Quality Norms, with nitrates concentration limits of $\sim 50 \mathrm{mg} / \mathrm{l}$ [37] [52] [53].

As can be observed in Figure 8 the mean nitrate values obtained for three settlements fall below the MCL recommended by WHO and ANOR. These results are in line with the observations and predictions of Groen (1988); that nitrate contamination generally increases in the older districts like Bependa and as well as densely populated areas (150 - $350 \mathrm{hts} / \mathrm{hectare})$. In this area all the samples exceed the contamination limit of $50 \mathrm{mg} / \mathrm{l}$ for drinking water. The high levels of nitrate $(72-241 \mathrm{mg} / \mathrm{l})$ could be related to more densely populated areas, which are in turn associated with many pit latrines [54]. In older districts like Bependa with poor sanitary conditions, though the nitrate content rises to an average of

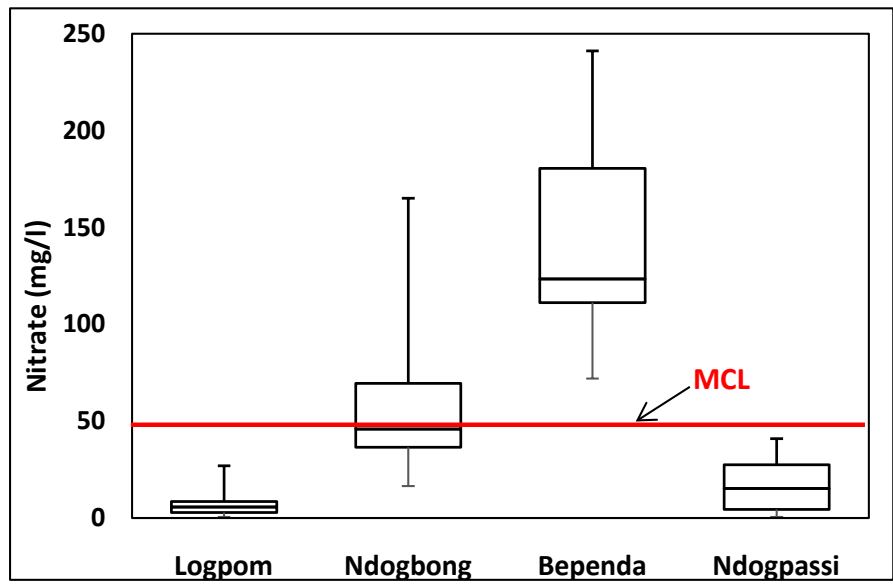

Figure 8. Nitrate concentration $(\mathrm{mg} / \mathrm{l})$ in the studied districts. 
$134 \mathrm{mg} / \mathrm{l}$, it still does not reach $400 \mathrm{mg} / \mathrm{l}$ that is observed in other big cities in West Africa [54] [55]. The relatively low nitrate contents can be explained by the fact that in the aqueous phase, the existence of the relative proportion of nitrogen in the form of $\mathrm{NH}_{3}$ and $\mathrm{NH}_{4}^{+}$is a function of the $\mathrm{pH}$ and the water temperature. A decrease in $\mathrm{pH}$ leads to the formation of ammonia, and high temperatures will induce nitrogen volatilization. Silicate in soils and the oxidation of organic matter are responsible for water acidity, and the de-nitrification factor that seems to protect Douala groundwater from contamination by nitrogen compounds.

In Ndogbong (population density 25 - 150 hts/hectare), the mean nitrate value is $59.6 \mathrm{mg} / \mathrm{l}$. Though the values obtained for $47.6 \%$ of the water samples are relatively low, they are still higher than the contamination limit recommended by WHO and ANOR. In Ndogpassi district with similar population density as Ndogbong, nitrate concentrations are lower. However, two samples exceed the MCL recommended by WHO and ANOR. The difference between the nitrate concentrations in the both districts (Figure 8) could be related to their age. It has been proven that the older district have nitrate values higher than the youngest districts.

Logpom presents the lowest nitrate concentration levels (average $=8.2 \mathrm{mg} / \mathrm{l}$ with a minimum $=0.6 \mathrm{mg} / \mathrm{l}$ and maximum $=27 \mathrm{mg} / \mathrm{l}$ ) which can also be linked to both the low population density, and the fact that it is the youngest district compared to others in this study.

Finally, sewage and urban runoffs are sources of nitrogen in the densely populated areas of Douala. Nitrate concentrations above the World Health Organization's Maximum Contaminant Level of $50 \mathrm{mg} / \mathrm{l}$ [52] are relatively common in some regions, especially in the emerging countries [56]. [23] observed that the average values and range were highest for shallow hand-dug wells and lowest for boreholes. This is because the water table for the commonly found hand-dug wells is shallow and hence more susceptible to the potential sources of $\mathrm{NO}_{3}^{-}$ contamination.

[57] indicated that the depth of a well is an important determinant of nitrate contamination. [58] observed significantly high amounts of nitrates in the first $20 \mathrm{~m}$ of the aquifers but decreases with depth, in the Banana plantations of Penja-Tiko ( 70 km north of Douala) and Mount the Cameroon area (SW of Cameroon). Because the wells in Bepanda are very shallow, we have plotted Nitrates versus depths only for Logpom and Ndogpassi wells which are relatively deeper compared to the other investigated areas.

The trend in Figure 9(a) shows that nitrates concentration increases with decrease in the depth in Logpom $(R=0.5)$. The frequency clearly indicates the type of nitrate in most of the analyzed groundwater samples are of superficial origin (anthropogenic). However, trends in Ndogpassi samples yielded increase nitrate concentrations with the depth from 0 to $9 \mathrm{~m}$ (Figure 9(b)). This trend can be explained by poor maintenance of the wells and/or total lack of cleaning. High $\mathrm{NO}_{3}^{-}$concentration in groundwater is indicative of the unconfined nature of 


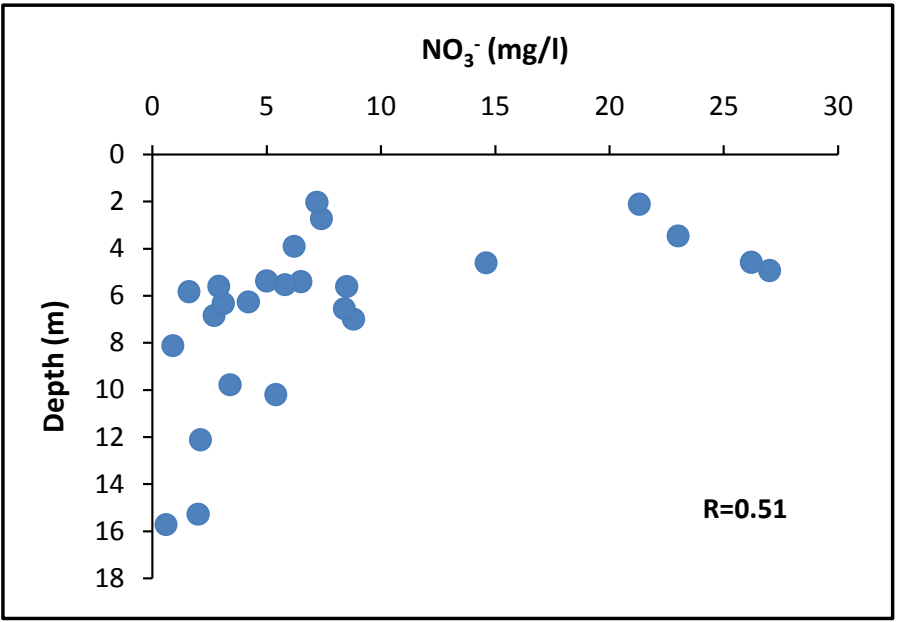

(a)

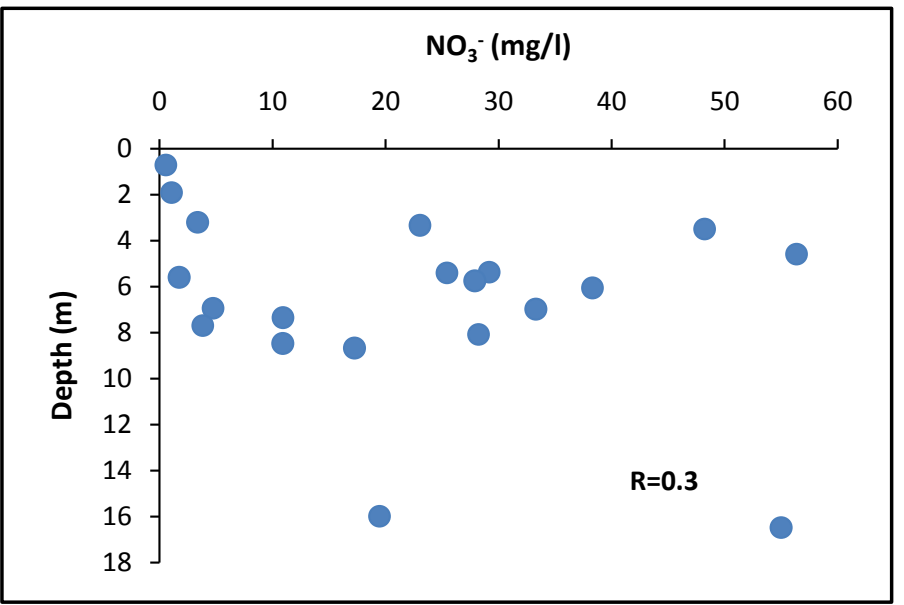

(b)

Figure 9. (a) A plot of depth of wells vs. nitrate concentrations in Logpom groundwater, (b) A plot of depth of wells vs. nitrate concentrations in Ndogpassi groundwater.

the aquifer system. Shallow groundwater sources (open wells and springs) are more vulnerable to nitrate contamination due to natural $\mathrm{N}$-fixing under aerobic conditions, while denitrification in reducing conditions is the probable cause of low nitrate concentration in waters from the deep boreholes in the Banana Plains (plantations).

The method currently used in the identification of groundwater contamination by sewage is the $\mathrm{NO}_{3}^{-} / \mathrm{Cl}^{-}$-diagram, in which $\mathrm{NO}_{3}^{-}$and $\mathrm{Cl}^{-}$are considered as tracers [44] [59]. The correlation between Nitrate and chloride concentrations in Ndogpassi (Figure 10(a)) and Ndogbong (Figure 10(b)) wells vary linearly. Meanwhile slight linearity in the Ndogpassi $(\mathrm{R}=0.61)$ and Ndogbong $(\mathrm{R}=0.84)$ suggests derivation from the same or similar source, the nitrate behaving conservatively and is not absorbed or transformed in the system [60]. This can be explained by contamination of the groundwater by sewage. Indeed, where sewage is the dominant contaminant, a close correlation between nitrate 


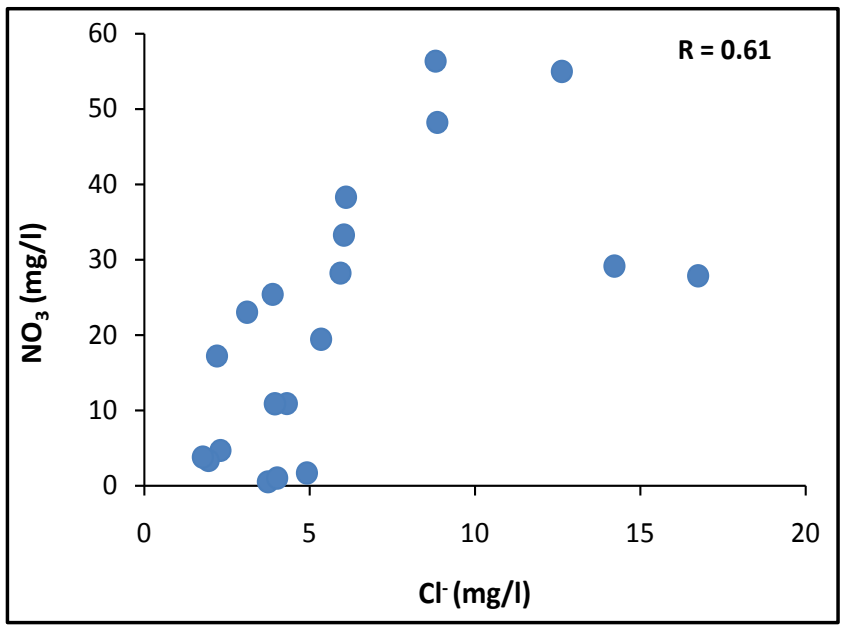

(a)

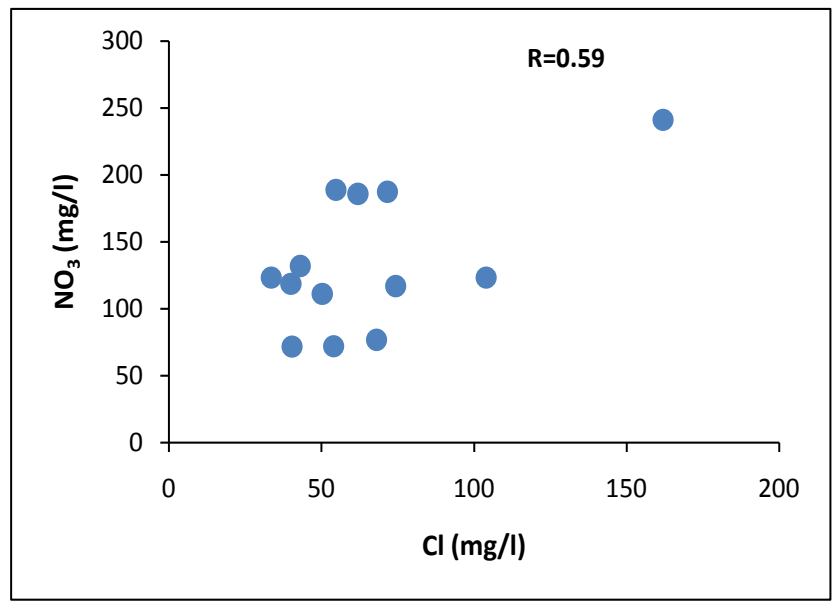

(c)

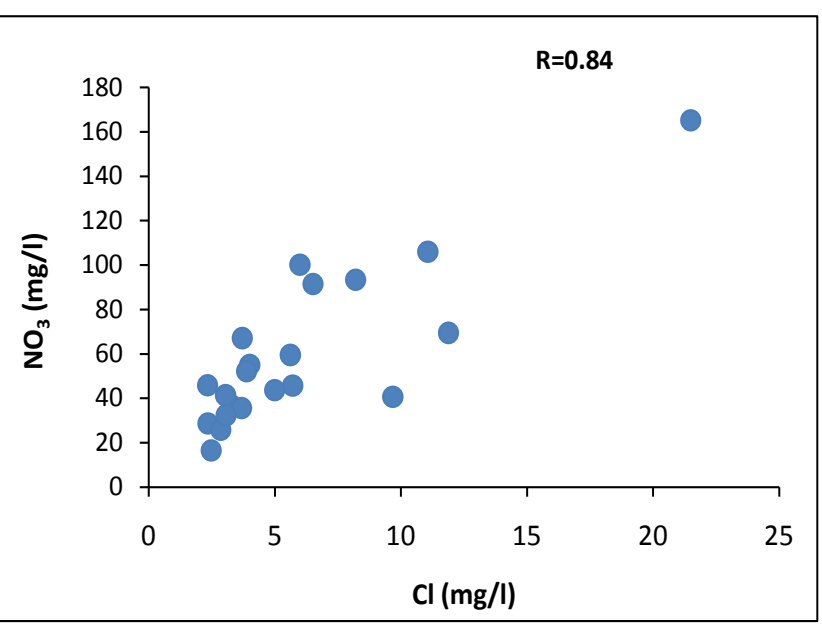

(b)

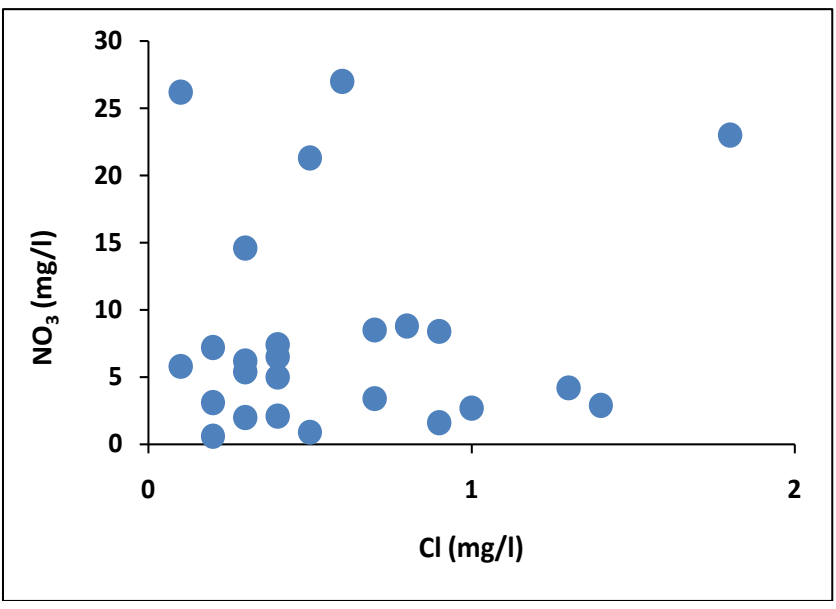

(d)

Figure 10. (a) Plot of nitrate concentrations Vs. chloride content in Ndogpassi district, (b) Plot of nitrate concentrations Vs. chloride content in Ndogbong district, (c) Plot of nitrate concentrations Vs. chloride content in Bependa district, (d) Plot of nitrate concentrations Vs. chloride content in Logpom district.

and chloride concentrations in groundwater is observed [60]. In complex urban setting, particularly which subjected to industrial contamination, such correlations may be masked [61]. This phenomenon is observed with Bependa samples which form a cluster and/or low correlation between nitrates and chlorides $(\mathrm{R}=$ 0.58) (Figure 10(c)). High levels of chlorides and nitrates are detected; which may indicate that organic matter is a major source of contamination for the Bependa aquifer [62]. The probably origin of the organic matter could be the municipal garbage landfill that existed in this neighborhood about 30 years ago. The results also indicate a possible leaching of nitrogen soil by leachate and the infiltration into the groundwater (unconfined aquifer).

$\mathrm{NO}_{3}^{-}$contents in groundwater are related to the decomposition of organic waste rejected and buried in the soil under various organic reactions (invertebrate, mushroom, bacteria), which produce $\mathrm{NH}_{4}^{+}$in the soil and then oxidizes to $\mathrm{NO}_{2}^{-}$and $\mathrm{NO}_{3}^{-}$[54] [63] [64] [65] according chemicals reactions below: 


$$
\begin{gathered}
\mathrm{NH}_{4}^{+}+\mathrm{H}_{2} \mathrm{O} \rightarrow \mathrm{NH}_{2} \mathrm{OH}+2 \mathrm{e}^{-}+\mathrm{H}^{+} \\
\mathrm{NH}_{2} \mathrm{OH}+\mathrm{O}_{2} \rightarrow \mathrm{NO}_{2}^{-}+\mathrm{e}^{-}+\mathrm{H}^{+} \\
\mathrm{NO}_{2}^{-}+\mathrm{H}_{2} \mathrm{O} \rightarrow \mathrm{NO}_{3}^{-}+2 \mathrm{e}^{-}
\end{gathered}
$$

In Logpom district, although there is no linear correlation between the nitrates and chlorides (Figure 10(d)) in the wells, the ratio between nitrate and chloride remains high $(0.15-262)$. This can be linked to the presence of human excrement in the water [56]. Indeed, the nitrogen in human excrement is relatively higher than the chloride.

Leaching of the waste in landfills and infiltration can thus contribute in raising the ratio of the two ions in groundwater [61].

\subsection{Health Risks Related to the Use of Contaminated Groundwater}

It is recognized that freshwater can be contaminated through anthropogenic activities [66], rapid industrialization, human population explosion, poor sanitary facilities and indiscriminate defecation, inadequate sewage and waste disposal. Common drinking water problems include exposure to toxic inorganic substances, heavy metals, bacterial and other pathogens, increased nitrogen concentrations and other trace chemicals, and micro-nutrients at the sources. Chemical contaminations are often considered a lesser priority than microbial contamination, because adverse health effects from chemical contaminations are generally associated with long-term exposure, whereas effects from microbial contaminations are usually immediate.

The bacteriological quality of water sources is based on estimation of fecal coliforms. Fecal coliform and streptococci are commonly used as indicator organisms for the microbiological quality of water. Analysis of 588 groundwater samples from Douala showed many germs (e.g. coliforms and fecal streptococci), which are indicators of fecal pollution. This study shows Bependa district has highest concentration of these germs $\left(9.06{ }^{*} 10^{3} \mathrm{cuf} / 100 \mathrm{ml}\right.$ of water). The later values are more than the [67] recommended treshold of cfu/100 $\mathrm{ml}$ for fecal coliforms. Nevertheless, considering local constraints, [68] proposes values of 20 $\mathrm{cfu} / 100 \mathrm{ml}$ water as acceptable limits in south Saharan Africa. However, Bependa values do exceed these values. The presence of fecal coliforms in most well can be explained by the movement of pollutants from closely located waste dumps, pit toilets and leaking septic tanks as well as indiscriminate defecation around wells. Fecal coliforms may indicate the presence of pathogens mainly bacteria, which are responsible for water-borne diseases such as cholera, diarrhea, typhoid and other gastro-intestinal disorder [69] [70]. Consequently, a series of cholera epidemics have been recorded in Douala in the last few years (in 2004 and 2012) [18] [71].

Contact of groundwater with nitrate concentrations of over $50 \mathrm{mg} / \mathrm{l}$ (MCL) are associated with a condition called methemoglobinemia or "blue-baby syndrome" in babies (6 - 0 months of age). Nitrate in drinking water used to make 
baby food is converted to nitrite in the baby's stomach. The nitrite then transforms the hemoglobin (the red-blood cells that carries oxygen) to methemoglobin which is unable to bind with oxygen, thus depriving the cells of oxygen. In extreme cases this health condition can result in death.

The portability of the groundwater in Logpom area for drinking and domestic purposes has been evaluated based on the World Health Organization (WHO, 2004) drinking water standards. According to [16] and [72], EC signifies the amount of total dissolved salts in water and also its inorganic load. Beside five samples from Bepanda, all the groundwaters in the study areas are within the recommended limits $(750 \mu \mathrm{S} / \mathrm{cm})$. Generally, the $\mathrm{pH}$ value of groundwaters is less than 6.5 (i.e. acidic). Compared with the WHO guideline for drinking water, only $22 \%$ of the samples were within the acceptable limits. Problems related to acidic groundwater include: corrosion of borehole casings, pipes and plumbing fixtures releasing toxic metals like lead, zinc, copper and cadmium into the water [73]. Groundwater $\mathrm{pH}<4.0$ gives a sour taste to the water especially when used for drinking.

Magnesium content ranges from $0.3 \mathrm{mg} / \mathrm{l}$ (in Ndogpassi sample) to $25.3 \mathrm{mg} / \mathrm{l}$ (in Bepanda sample) with an average of $2.6 \mathrm{mg} / \mathrm{l}(\mathrm{n}=79)$. All the samples analyzed are within the permissible limit. Sulfate is one of the least toxic anions, even though dehydration is observed at high concentrations. WHO (2004) recommended an upper sulfate limit of $250 \mathrm{mg} / \mathrm{l}$. If the sulfate exceeds the later threshold, it may cause gastrointestinal irritation and laxative effect at much higher concentrations (WHO, 1993). Sulfate values in the groundwater samples of the study area vary from 0 (in Bepanda, Ndogbong and Ndogpassi) to 62.6 (in Bepanda) $\mathrm{mg} / \mathrm{l}$ with an average of $8.9 \mathrm{mg} / \mathrm{l}(\mathrm{n}=79)$. All the samples show sulfate contents within the recommended limit. Sodium is the most dominant cation in groundwater. Sodium $(\mathrm{Na})$ concentration of more than $50 \mathrm{mg} / \mathrm{l}$ makes water unsuitable for domestic use [74]. The recommended WHO limit for sodium concentration in drinking water is $200 \mathrm{mg} / \mathrm{l}$. A higher sodium intake may cause hypertension, congenial heart diseases, and kidney problems. Concentrations of sodium are within the prescribed limit of $200 \mathrm{mg} / \mathrm{l}$ in all the analyzed water samples. Potassium ions $\left(\mathrm{K}^{+}\right)$are also found within the permissible limits. 31.6\% of the samples have $\mathrm{NO}_{3}$ concentration greater than the limit of $10 \mathrm{mg} / \mathrm{l}$; all the samples from Bepanda and approximately $50 \%$ of Ndogbong samples exceed the $\mathrm{NO}_{3}$ limit of $50 \mathrm{mg} / \mathrm{l}$ (Table 1).

\section{Conclusion}

The study of factors influencing water quality in four districts revealed that Logpom, the youngest of the four districts with lower population density is in a better situation in terms of natural characteristics and the anthropogenic effects that influence water quality; and because the water table is amongst the deepest in Douala. The nitrate concentration in the groundwater is still relatively low compared to other districts in West Africa because of the ammoniac volatiliza- 
tion. Finally, based on this research, it is recommended that control of waste disposal by regulatory bodies should be enforced and recycling of industrial effluents should be done to reduce the flow into the groundwater systems.

\section{References}

[1] United Nations Educational, Scientific and Cultural Organization (2004) Groundwater Resources on the World and Their Use. United Nations Educational, Scientific and Cultural Organization, Paris, 342.

[2] British Geological Survey (2002) Groundwater Quality: Mali. http://www.bgs.ac.uk/downloads/start.cfm?id=1284

[3] De Waele, J., Nyambe, I.A., Di Gregorio, A., Di Gregorio, F., Simasiku, S., Follesa, R. and Nkemba, S. (2004) Urban Waste Landfill Planning and Karstic Groundwater Resources in Developing Countries: The Example of Lusaka (Zambia). Journal of African Earth Sciences, 39, 501-508. https://doi.org/10.1016/j.jafrearsci.2004.07.014

[4] Ikem, A., Odueyungbo, S., Egiebor, N.O. and Nyavor, K. (2001) Chemical Quality of Bottled Waters from Three Cities in Eastern Alabama. Science of the Total Environment, 285, 165-175. https://doi.org/10.1016/S0048-9697(01)00915-9

[5] Cisse, S., Faye, S. and Gaye, C.B. (2000) Effect of Rapidly Urbanizing Environment on the Thiaroye Area (Senegal). Environmental Geology, 45, 321-322.

[6] Chopra, R.P.S. and Krishan, G. (2014) Assessment of Groundwater Quality in Punjab, India. Journal of Earth Science \& Climatic Change, 5, 3.

[7] Monna, F., Petit, C., Guillaumet, J.P., Jouffroy-Bapicot, I., Blanchot, C., Dominik, J., Losno, R., Richard, H., Lévêque, J. and Château, C. (2004) History and Environmental Impact of Mining Activity in Celtic Aeduan Territory Recorded in a Peat Bog (Morvan, France). Environmental Science \& Technology, 38, 665-673. https://doi.org/10.1021/es034704v

[8] Krishan, G., Rao, M.S., Kumar, C.P. and Prabhat, S. (2013) Identifying Salinization Using Isotopes and Ion Chemistry in Semi-Arid Region of Punjab, India. Journal of the Geological Society, 2, 5.

[9] Hassan, M.M., El Shiwi, M. and Smidt, E. (1995) Impact of Sewage Systems on Groundwater Heads in Eastern Cairi Region. Water Science and Technology, 32, 171-177. https://doi.org/10.1016/0273-1223(96)00131-X

[10] El Arabi, N.E. (1999) Problems of Groundwater Quality Related to the Urban Environment in Greater Cairo. Proceedings of the International Union of Geological Sciences Symposium, Birminghan, 18 July, 29-37.

[11] Szabo, G., Angyal, A., Csisko, A., Bessenyei, E., Toth, E., Kiss, P., Csorba, P. and Szabo, S. (2010) Examination of Groundwater Pollution at Lowland Settlements. Studia Universitatis, Seria Stiintele Vietti, 20, 89-95.

[12] Mahler, R.L., Porter, E. and Taylor, R. (1988) Quality of Water for Idaho. McGraw Hill, New York, 17-20.

[13] Colleen, S. (1993) The Effect of Nitrate, Nitrite and N-Nitrous-Compounds on Human Health. Veterinary and Human Toxicology Review, 35, 521-538.

[14] Tandia, A.A., Gaye, C.B. and Faye, A. (1997) Origine des Teneurs Elevées en Nitrates dans la Nappe Phréatique des Sables Quaternaires de la Région de Dakar, Sénégal. Article Scientifique Sécheresse, 8, 291-294.

[15] Kulabako, N.R., Nalubega, M. and Thunvik, R. (2007) Study of the Impact of Land Use and Hydrogeological Settings on the Shallow Groundwater Quality in a Peri- 
Urban Area of Kampala, Uganda. Science of the Total Environment, 381, 180-199. https://doi.org/10.1016/j.scitotenv.2007.03.035

[16] Goss, M.J., Barry, D.A.J. and Rudolph, D.L. (1998) Contamination in Ontario Farmstead Domestic Wells and Its Association with Agriculture: Results from Drinking Water Wells. Journal of Contaminant Hydrology, 32, 267-293. https://doi.org/10.1016/S0169-7722(98)00054-0

[17] Baojing, G., Ying, G., Scott, X., Weidong, L. and Jie, C. (2013) Nitrate in Groundwater of China: Sources and Driving Forces. Global Environmental Change, 23, 1112-1121. https://doi.org/10.1016/j.gloenvcha.2013.05.004

[18] Guévart, N.J., Solle, J., Essomba, J.M., Edjenguele, M., Bita, A., Mouangue, A. and Manga, B. (2006) Determinants of Cholera in Douala. Tropical Physician, 66, 283291.

[19] Mafany, G.T. (199) Impact of Geology and Seawater Intrusion on Groundwater Quality in Douala. Master's Thesis, Buea University, Buea, 100.

[20] Ndjama, J., et al. (2008) Water Supply, Sanitation and Health Risks in Douala, Cameroon. African Journal of Environmental Sciences and Technology, 2, 422-429.

[21] Djuikom, E., Temgoua, E., Jugnia, L.B., Nola, M. and Baane, M. (2009) Pollution Bactériologique des Puits d'eau Utilisés par les Populations dans la Communauté Urbaine de Douala. International Journal of Biological and Chemical Sciences, 3, 967-978.

[22] Takem, E.G., Chandrasekharam, D., Ayomghe, S.N. and Thambidurai, P. (2010) Pollution Characteristics of Fluvial Groundwater from Springs and Bore Wells in Semi-Urban Informal Settlements of Douala-Cameroon, Western Africa. Environmental Earth Sciences, 61, 287-298. https://doi.org/10.1007/s12665-009-0342-8

[23] Ngo Boum-Nkot, S., Ketchemen-Tandia, B., Nje, Y., Emvouttou, H., Ebonji, S. and Huneau, F. (2015) Origin of Mineralization of Groundwater in Tongo Bassa Watershed (Douala-Cameroon). Journal of Hydrogeology and Hydrologic Engineering, 4,1 .

[24] Takem, E.G., Kuitcha, D., Ako, A.A., Mafany, G.T., Takounjou-Fouepe, A., Ndjama, J., Ntchancho, R., Ateba, B.H. and Chandrasekharam, D. (2015) Acidification of Shallow Groundwater in the Unconfined Sandy Aquifer of City of Douala, Cameroon, Western Africa: Implications for Groundwater Quality and Use. Environmental Earth Sciences, 74, 1-16. https://doi.org/10.1007/s12665-015-4681-3

[25] Angwe, C.A. and Gabehe, C.E. (1997) Quantitative Estimation of Land Based Sources of Pollution to the Costal and Marine Environment of the Republic of Cameroon, FAO Contract. Food and Agriculture Organization, Rome, 25.

[26] Institut National de la Statistique du Cameroun (2010) Etude Préliminaire sur l'Economie Locale de la Ville de Douala. Institut National de la Statistique du Cameroun, Yaoundé.

[27] Institut National de Statistique (2007) Conditions de Vie des Populations et Profil de Pauvreté au Cameroun en 2007, Rapport Principal de l'Ecam 3. Institut National de Statistique, Yaoundé, 157.

[28] Dumort, J.C. (1968) Notice Explicative sur la Feuille de Douala-Ouest. Carte Géologique de Reconnaissance à l'Echelle 1/50000. Direction des Mines et de la Géologie du Cameroun. République Fédérale du Cameroun, Yaoundé, 69.

[29] Regnoult, J.M. (1986) Synthèse Géologique du Cameroun DMG. Cameroun Data Management Group, Yaoundé, 199. 
[30] Tamfu, S. and Batupe, M. (1995) Geologic Setting, Stratigraphy and Hydrocarbon Habitat of the Douala Basin, Cameroon. National Hydrocarbon Journal of Cameroon, 3, 6 .

[31] Manga, C.S. (2008) Stratigraphy, Structure and Prospectively of the Southern Onshore Douala Basin, Cameroon-Central Africa. Cameroon and Neighboring Basins in the Gulf of Guinea. Africa Geoscience Review, 5, 13-37.

[32] Ndomè, E.P.E. (2010) Mineralogy, Geochemistry and Geotechnical Applications of Weathering Products of Sedimentary Rocks of Douala. Ph.D. Thesis, Univ. Yaoundé I, Yaoundé, 212.

[33] Djeuda-Tchapnga, H.B., Tanawa, E. and Ngnikam, E. (2001) L'eau au Cameroun. Presses Universitaires, Yaoundé, 115-129.

[34] Ketchemen-Tandia, B., Ntamak-Nida, M.J., Ngo Boum-Nkot, S., Wonkam, C., Emvoutou, H., Ebonji Seth, C. and Aranyoussy J.F. (2007) First Results of Isotopic Studies $(18 \mathrm{O}, 2 \mathrm{H}, 3 \mathrm{H})$ of the Quaternary Aquifer of Douala Basin (Cameroon). Note et mém. Serv. Géol. Maroc, 516, 77-88.

[35] Appelo, C.A.J. and Postma, D. (1999) Chemical Analysis of Groundwater, Geochemistry, Groundwater \& Pollution. Balkema, Rotterdam.

[36] Simler, R. (2007) Diagrammes. Laboratoire d'Hydrogéologie d'Avignon, Université d'Avignon, Logiciel d'hydrochimie Multi Langage en Distribution Libre, Avignon.

[37] World Health Organization (WHO) (2004) Guidelines for Drinking Water Quality. World Health Organization, Geneva.

[38] Szabo, G., Vince, T. and Bessenyei, E. (2012) Study of the Factors Influencing the Shallow Groundwater Quality in Two Settlements with Different Characteristics. In: Dr. Voudouris, Ed., Water Quality Monitoring and Assessment, InTech, Debrecen, 408-428. https://doi.org/10.5772/33598

[39] Szalai, Z. (2008) Spatial and Temporal Pattern of Soil pH and Eh and Their Impact on Solute Iron Content in a Wetland (Transdanubia, Hungary). Acta Geographica Debrecina Landscape \& Environment, 2, 34-45.

[40] Massoud, E.A.A. (2013). Hydrochemical Characteristic and Evaluation of Groundwater Quality in Wadi as Sab'an, Western Saudi Arabia. International Journal of Engineering Research, 4, 10.

[41] Dafny, E., Burg, A. and Gvirtzman, H. (2006) Deduction of Groundwater Flow Regime in a Basaltic Aquifer Using Geochemical and Isotopic Data: The Golan Heights, Israel Case Study. Journal of Hydrology, 330, 506-524. https://doi.org/10.1016/j.jhydrol.2006.04.002

[42] Adams, S., Titusa, R., Pietersen, K., Tredoux, G. and Harris, C. (2001) Hydrochemical Characteristics of Aquifers near Sutherland in the Western Karoo. African Journal of Hydrology, 241, 91-103. https://doi.org/10.1016/S0022-1694(00)00370-X

[43] Stumm, W. and Morgan, J.J. (1981) Aquatic Chemistry. Wiley and Sons, New York.

[44] Tiwari, A.K. and Singh, A.K. (2014) Hydrogeochemical Investigation and Groundwater Quality Assessment of Pratapgarh District, Uttar Pradesh. Journal of the Geological Society of India, 83, 329-343. https://doi.org/10.1007/s12594-014-0045-y

[45] Piper, A.M. (1944) A Graphic Procedure in Geochemical Interpretation of Water Analysis. Transactions of American Geophysical Union, 25, 914-928. https://doi.org/10.1029/TR025i006p00914

[46] Abid, K. (2010) Identification et Caractérisation Hydrogéologique et Géochimique de la Nappe du Turonien dans le Sud Tunisien et sa Relation avec les Aquifères 
Adjacents. Ph.D. Thesis, University of Sfax, Sfax.

[47] Abid, K., Trabelsi, R., Zouari, K. and Abidi, B. (2009) Caractérisation Hydrogéochimique de la Nappe du Continental Intercalaire (Sud Tunisien). Journal des Sciences Hydrologiques, 54, 526-537. https://doi.org/10.1623/hysj.54.3.526

[48] Kebede, S., Travi, Y., Alemayehu, T. and Ayenew, T. (2005) Groundwater Recharge, Circulation and Geochemical Evolution in the Source Region of the Blue Nile River, Ethiopia. Applied Geochemistry, 20, 1658-1676. https://doi.org/10.1016/j.apgeochem.2005.04.016

[49] Marghade, D., Malpe, D.B. and Zade, A.B. (2011) Major Ion Chemistry of Shallow Groundwater of a Fast Growing City of Central India. Environmental Monitoring \& Assessment, 184, 2405-2418. https://doi.org/10.1007/s10661-011-2126-3

[50] Jalali, M. (2009) Geochemistry Characterisation of Groundwater in an Agricultural Area of Razan, Hamadan, Iran. Environmental Geology, 56, 1479-1488. https://doi.org/10.1007/s00254-008-1245-9

[51] Appelo, C.A.J. and Postma, D. (1996) Geochemistry, Groundwater \& Pollution. Balkema, Rotterdam.

[52] World Health Organization (2011) Guidelines for Drinking-Water Quality. 4th Edition, World Health Organization, Geneva.

[53] Agence Nationale des Normes et Qualité (2003) Cameroon Drinking Water Quality Norms (NC 207: 2003-02). Agence Nationale des Normes et Qualité, Yaoundé.

[54] Tandia, A.A. (2000) Origine, Evolution et Migration des Formes de l'Azote Minéral dans les Aquifères Situés sous Environnement Périurbain non Assaini: Cas Dessables Quaternaires de la Région de Dakar (Sénégal). Université Cheikh Anta Diop de Dakar, Dakar, 210.

[55] Greon, J., Schumann, J.B. and Geinaert, W. (1988) The Occurrence of High Nitrate Concentration in Groundwater in Villages in Northwestern Burkina Faso. Journal of African Earth Sciences, 7, 999-1009. https://doi.org/10.1016/0899-5362(88)90013-9

[56] Townsend, A.R., Robert, W.H., Fakhri, A.B., Mary, S., Cory, C.C., Sharon, K.C. and Andrew, P.D. (2003) Human Health Effects of a Changing Global Nitrogen Cycle. Frontiers in Ecology and the Environment, 1, 240-246. https://doi.org/10.1890/1540-9295(2003)001[0240:HHEOAC]2.0.CO;2

[57] Kross, B.C., Hallberg, G.R., Bruner, D.R., Sherry, H.K. and Johnson, J.K. (1993) The Nitrate Contamination of Private Well Water in Iowa. American Journal of Public Health, 83, 270-272. https://doi.org/10.2105/AJPH.83.2.270

[58] Ako, A.A., Eyong, T.G.E., Shimada, J., Koike, K., Hosono, T., Ichiyanagi, K., Akoachere, R., Ketchemen-Tandia, B., Elambo, N.G. and Ntankouo, N.R. (2013) Nitrate Contamination of Groundwater in Two Areas of the Cameroon Volcanic Line (Banana Plain and Mount Cameroon Area). Applied Water Science, e4, 99-113.

[59] Chilton, P.J., Lawrence, A.R. and Stuart, M.E. (1994) The Impact of Tropical Agriculture on Groundwater Quality in Groundwater Quality. Chapman \& Hall, London.

[60] Wang, B., Strelakos, P.M. and Jokela, B. (2000) Nitrate Source Indicators in Ground Water of the Scimitar Subdivision, Peters Creek Area, Anchorage, Alaska. U.S. Geological Survey. Water-Resources Investigations Report, 413, 25.

[61] Howard, K.W.F. and Israfilov, R.G. (2001) Current Problems of Hydrogeology in Urban Areas, Urban Agglomerates and Industrial Centers. NATO Sciences, Earth \& Environmental Sciences. Kluwer Academic Publishers, Dordrecht, 501. 
[62] Tom, C. (1993) High Chloride Concentrations in Groundwater Withdrawn from above Sea Level Aquifers. Whidbey Island, Washington. Ontario Federation of Trail Riders, Markham.

[63] Mariotti, A. (1983) Utilisation des Variations Naturelles d'Abondance Isotopique en $15 \mathrm{~N}$ comme Traceur de l'Origine des Pollutions des Aquifères par les Nitrates. Compte Rendu du Colloque International sur l'Hydrologie Isotopique et la Mise en Valeur des Ressources en eau. Autriche, Vienne.

[64] Sebilo, M. (2003) Utilisation du Traçage Isotopique Naturel pour Caractériser et Quantifier les Processus de Nitrification et Dénitrification à l'Echelle du Réseau Hydrographique de la Seine. L'Université Pierre et Marie Curie, Paris.

[65] Briand, C. (2014) Approche Multi-Traceurs pour la Détermination de l'Origine des Nitrates dans les eaux Souterraines: Exemple d'une Source Karstique dans les Landes. L'Université Pierre et Marie Curie, Paris.

[66] Masson, B. (1966) Principe of Geochemistry. John Wiley and Sons, New York.

[67] World Health Organization (2006) Guidelines for Drinking-Water Quality, V.1, Recommendations. World Health Organization, Geneva.

[68] Viland, M., Montiel, A., Duchemin, J., Lariviere, M. and Zarrabi, P. (1993) Eau et Santé: Guide Pratique pour les Intervenants en Milieu Rural Africain ps-eau. Editions du Gret, Paris, 114.

[69] Obire, O. and Agunda, M. (2002) Bacterial Community of Leachate from a Waste Dump an Adjacent Stream in Nigeria. Journal of Environmental Science and Management, 6, 71-75.

[70] Mkandawire, T. (2008) Quality of Groundwater from Shallow Wells of Selected Villages in Blantyre District, Malawi. Physics and Chemistry of the Earth, 33, 807811. https://doi.org/10.1016/j.pce.2008.06.023

[71] Ketchemen-Tandia, B. and Banton, O. (2012) Les Etudes Hydrogéologiques comme Outils Complémentaires aux Moyens de Prévention des Maladies Hydriques, Sénégal Communication Personnelle.

[72] Davis, S.N. and De Wiest, R.J.M. (1966) Hydrogeology. Wiley, New York.

[73] Laherno, P. (1991) Aspects of Acidification of Groundwater in Finland. Geological Survey of Finland, Special Paper, 9, 131-139.

[74] Nagarajan, R., Rajmohan, N., Mahendran, U. and Senthamilkumar, S. (2009) Evaluation of Groundwater Quality and Its Suitability for Drinking and Agricultural Use in Thanjavur City, Tamil Nadu, India. Environmental Monitoring \& Assessment, 171, 289. https://doi.org/10.1007/s10661-009-1279-9 
Submit or recommend next manuscript to SCIRP and we will provide best service for you:

Accepting pre-submission inquiries through Email, Facebook, LinkedIn, Twitter, etc. A wide selection of journals (inclusive of 9 subjects, more than 200 journals)

Providing 24-hour high-quality service

User-friendly online submission system

Fair and swift peer-review system

Efficient typesetting and proofreading procedure

Display of the result of downloads and visits, as well as the number of cited articles Maximum dissemination of your research work

Submit your manuscript at: http://papersubmission.scirp.org/

Or contact gep@scirp.org 